Jurnal SMART Keperawatan, 2021, 8 (2), 142-148

SJKP 2021

DOI: http://dx.doi.org/10.34310/jskp.v8i2.515

pISSN 2301-6221; elSSN 2502-5236

http://stikesyahoedsmg.ac.id/ojs/index.php/sjkp

\title{
DEMONSTRASI PENGGUNAAN FIRST AID KITS TERHADAP PENINGKATAN PENGETAHUAN DAN SKILLS SISWA DALAM PENANGANAN CEDERA DI SEKOLAH
}

\section{DEMONSTRATION OF THE USE FIRST AID KITS TO IMPROVE STUDENT'S KNOWLEDGE AND SKILLS IN INJURY MANAGEMENT AT SCHOOL}

\author{
Dewi Rachmawati $\bowtie$ \\ Prodi D3 Keperawatan Blitar, Jurusan Keperawatan, Poltekkes Kemenkes Malang \\ Correspondence Email: dewi_rachmawati@poltekkes-malang.ac.id
}

\begin{abstract}
ABSTRAK
Cedera sering terjadi pada anak terutama saat di sekolah. Cedera menyebabkan kecacatan bahkan kematian anak, sehingga siswa harus mampu memberikan pertolongan atau upaya penanganan cedera. Tujuan penelitian untuk mengetahui pengaruh demonstrasi penggunaan first aid kits terhadap peningkatan pengetahuan dan skills siswa dalam penanganan cedera di sekolah. Desain penelitian adalah quasy-experimental metode one group pretest-posttest design. Sampel berjumlah 42 orang, dengan teknik proportionate stratified random sampling. Instrumen untuk mengukur pengetahuan menggunakan kuesioner dan keterampilan dengan lembar observasi dan analisa data menggunakan paired sample $t$-test. Hasil menunjukkan nilai rata-rata pengetahuan dan keterampilan sebelum intervensi adalah 12,95 dan 53,14. Setelah dilakukan intervensi nilai rata-rata pengetahuan dan keterampilan adalah 18,64 dan 68,12 dengan $\mathrm{p}$ value 0.000 yang artinya ada pengaruh demonstrasi penggunaan first aid untuk meningkatkan pengetahuan dan keterampilan siswa. Demonstrasi yang dilakukan peserta didik akan memperoleh pengalaman melalui percontohan atau pertunjukan dan memberikan $70 \%$ pemahaman dan daya ingat terkait keterampilan yang diperagakan.
\end{abstract}

Kata kunci: demonstrasi; first aid kits; pengetahuan; skills

\section{ABSTRACT}

Injuries are common in children, especially at school. Injuries cause disability and even death of children, in case, that student must be able to provide assistance or efforts to treat injuries. The purpose of the study was to determine the effect of demonstrations on the use of first aid kits to increase students' knowledge and skills in handling injuries at school. The research design was a quasy-experimental one group pretest-posttest design method. The sample was 42 people, with proportionate stratified random sampling technique. Instruments to measure knowledge used questionnaires and skills with observation sheets and data analysis using paired sample t-test. The results showed that the average value of knowledge and skills before the intervention was 12.95 and 53.14. After the intervention, the average value of knowledge and skills was 18.64 and 68.12 with a $p$ value of 0.000 , which means that there was an effect of demonstration of using first aid to improve students' knowledge and skills. Demonstrations carried out by students are able to gain experience through demonstrations or performances and provide $70 \%$ understanding and memory related to the skills being demonstrated.

Keywords: demonstration; first aid kits; knowledge; skills

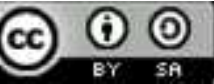

Jurnal SMART Keperawatan is licensed under a Creative Commons Attribution-ShareAlike 4.0 International License 


\section{PENDAHULUAN}

Cedera anak merupakan suatu masalah global yang harus mendapatkan perhatian. Anak memiliki ukuran tubuh yang lebih kecil sehingga rentan sekali terjadi cedera. Terdapat berbagai penyebab dari cedera pada anak meliputi penyebab yang disengaja (intentional injury), penyebab yang tidak disengaja (unintentional injury) dan penyebab yang tidak bisa ditentukan (undeterminated intend). Penyebab tidak disengaja mempunyai prevalensi yang tertinggi mengakibatkan cedera pada anak, antara lain terjadinya kecelakaan lalu lintas/transportasi darat/laut/udara, jatuh dari ketinggian, terbakar/tersiram, luka akibat benda tajam/tumpul/mesin/ledakan, bencana alam dan cedera olahraga, dengan dampak yang dialami antara lain gangguan fisik seperti hilangnya sebagian atau kurang berfungsinya anggota badan, kecacatan fisik permanen dan tingginya biaya perawatan. (Russel et al, 2004; Badan Penelitian dan Pengembangan Kesehatan Kemenkes RI, 2018).

Di Indonesia proporsi cedera adalah 9,2\% dengan proporsi cedera tertinggi pada kelompok umur 15-24 tahun yaitu 12,2\%. Tempat terjadinya cedera paling banyak kedua adalah disekolah dengan proporsi 8,4\%. Lingkungan sekolah menjadi tempat tertinggi kedua yang sering mengalami cedera disebabkan karena sekolah merupakan rumah kedua bagi siswa dengan berbagai aktivitas yang dapat dilakukan seperti bermain, melakukan praktik keterampilan dan kegiatan olahraga (Badan Penelitian dan Pengembangan Kemenkes RI, 2014). Pertolongan pertama kegawatdaruratan dan cedera yang terjadi di sekoah dapat menurunkan angka kematian dan kecacatan (Abd El-Hay, Ibrahim \& Hassan, 2015). Untuk itu sebagai upaya agar cedera yang terjadi tidak semakin serius maka diperlukan pertolongan pertama pada saat terjadi cedera.

Pertolongan pertama adalah pertolongan atau tindakan awal yang diberikan kepada seseorang yang mengalami cedera atau tiba-tiba sakit. Pertolongan pertama ini dilakukan untuk mencegah timbulnya cedera yang lebih parah terhadap korban dengan prioritas tindakan melakukan identifikasi korban dan melakukan tindakan sedini mungkin untuk mencegah kematian maupun kecacatan. Pertolongan pertama ini dapat dilakukan oleh siapapun dan dalam situasi apapun, antara lain polisi, pemadam kebakaran, paramedis, orang awam, guru maupun siswa jika itu disekolah (Piazza, 2014).

Seseorang dalam memberikan pertolongan pertama harus mempunyai pengetahuan, keterampilan dan pengalaman dalam menolong. Pertolongan pertama merupakan suatu hal krusial yang harus dilakukan untuk mencegah fatalnya cedera. Kesalahan dalam memberikan pertolongan dapat berakibat fatal terhadap korban. Selain itu penolong juga harus mempunyai pengetahuan dan keterampilan tentang penggunaan peralatan first aid untuk menolong (Piazza, 2014).

Salah satu upaya yang dilakukan untuk meningkatkan penggetahuan dan skills penggunaan first aid kits adalah dengan memberikan pendidikan kesehatan. Metode demonstrasi adalah metode mengajar dengan cara memperagakan barang, kejadian, aturan, dan urutan melakukan suatu kegiatan, baik secara langsung maupun melalui media pengajaran yang relevan dengan pokok bahasan atau materi yang sedang disajikan (Syah, 2011). Metode ini merupakan suatu cara penyajian dengan menggunakan alat atau memperagakan sesuatu proses, situasi dan hal tertentu yang mempermudah proses belajar dan metode ini membawa siswa pada kondisi seperti kenyataan yang melibatkan penjelasan secara lisan (Djaramah \& Zain, 2012). Dibuktikan dengan penelitian Yusniawati dkk (2020) yang menyatakan bahwa dengan metode demonstrasi secara langsung maka dapat meningkatkan pengetahuan siswa SMA dalam memberikan pertolongan pertama korban kecelakaan. Diperkuat oleh Prasetyawan dkk (2019) yang juga menyatakan bahwa demonstrasi dapat meningkatkan pengetahuan siswa SMA tentang pertolongan pertama. 
SMK 3 Blitar merupakan sekolah kejuruan dengan kegiatan belajar lebih banyak melakukan praktikum. Kegiatan belajar praktikum ini berisiko menyebabkan cedera pada siswa. Cedera yang mungkin terjadi antara lain patah tulang, terkilir, perdarahan maupun mimisan. Guru dan siswa di sekolah adalah orang pertama yang mengetahui apabila terjadi cedera. Berdasarkan studi pendahuluan menyatakan hanya 15\% guru dan beberapa siswa di SMK yang tahu bagaimana memberi pertolongan pertama karena mengikuti kegiatan PMR. Sesuai dengan penelitian Abd ElHay, Ibrahim \& Hassan (2015) menyatakan bahwa rata-rata pengetahuan dan keterampilan siswa kurang tentang first aid dan basic life support. Diperkuat dengan penelitian Maguluru et al (2018) yang menyatakan pengetahuan siswa kurang tentang penatalaksanaan cedera sebelum dilakukan pelatihan. Untuk itu dilakukan penelitian pengaruh demontrasi penggunaan first aid kits terhadap peningkatan pengetahuan dan skills penanganan cedera pada siswa SMK.

\section{METODE}

Penelitian ini menggunakan desain quasyexperimental dengan metode one group pretestposttest design di SMK 3 Kota Blitar pada tanggal 6 Oktober 2018. Subjek penelitian adalah siswa SMK 3 Blitar yang berjumlah 42 orang. Teknik pengambilan sampel yang digunakan adalah proportionate stratified rondom sampling. Tahap pertama dalam mengambil sampel adalah menentukan ukuran sampel yang harus diambil dari setiap subpopulasi (jurusan) dan tahap selanjutnya adalah menentukan sampel sasaran atau responden dengan cara pengambilan sampel random sederhana melalui pengundian nomor absen masing-masing anggota subpopulasi (jurusan) sampai didapatkan 42 sampel. Instrumen yang digunakan adalah kuesioner dengan jumlah soal sebanyak 15 soal. Kriteria penilaian kuesioner adalah untuk nomor soal 1-3 mengacu pada penilaian apabila responden menjawab benar $<2$ mendapatkan nilai 1 , bila responden menjawab dengan benar
2-3 jawaban mendapatkan nilai 2, bila responden menjawab dengan benar 4 jawaban mendapatkan nlai 3 dan bila reponden menjawab dengan benar $>4$ jawaban maka mendapatkan nilai 4. Sedangkan untuk nomor 4-15 penilaian yang diberikan apabila menjawab benar mendapatkan skor 1 dan apabila menjawab salah mendapatkan skor 0 . Hasil uji validitas didapatkan nilai $r$ hitung lebih besar 0,396 ( $r$ tabel) sehingga dinyatakan soal adalah valid. Untuk hasil uji reliabilitas dengan Cronbach Alpha pada nomor soal 1-3 didapatkan koefisien Cronbach Alpha sebesar 0,844 dan soal 4-15 didapatkan koefiesien 0,912. Karena nilai koefisien reliabilitasnya lebih besar dari 0,6 maka instrumen untuk mengukur pengetahuan dinyatakan reliabel/andal.

Pelaksanaan penelitian diawali dengan meminta persetujuan responden kemudian mengukur pengetahuan dengan membagikan kuesioner pertama (pretest) selama 15 menit dan observasi keterampilan sebelum diberikan pendidikan kesehatan, selanjutnya memberikan pendidikan kesehatan metode demonstrasi selama 90 menit, diakhiri dengan memberikan kuesioner kedua (posttest) dan observasi keterampilan untuk mengetahui perbedaan pengetahuan dan keterampilan setelah diberikan pendidikan kesehatan. Analisis data yang digunakan adalah analisis univariat untuk menggambarkan nilai minimal, maksimal mean, median dan standar deviasi. Untuk mengetahui pengaruh metode demontrasi terhadap pengetahuan dan skills menggunakan uji statistik Paired Sample t-test.

\section{HASIL}

Berdasarkan karakteristik responden pada tabel 1 menunjukkan bahwa dari total 42 responden sebanyak 90\% (38 siswa) berjenis kelamin perempuan, $55 \%$ (23 siswa) berusia 16 tahun, $79 \%$ (33 siswa) pernah mendapatkan informasi tentang first aid kits dan 42\% (18 siswa) mempunyai sumber informasi cukup tentang first aid

kits. 
Tabel 1 Karakteristik Umum Responden Siswa SMK 3 Blitar ( $n=42)$

\begin{tabular}{llcc} 
Karakteristik & & Jumlah & $\%$ \\
\hline Jenis Kelamin & Laki-laki & 4 & 10 \\
& Perempuan & 38 & 90 \\
\hline Usia & 15 tahun & 15 & 35 \\
& 16 tahun & 23 & 55 \\
\multirow{2}{*}{ Mendapatkan Informasi } & 17 tahun & 4 & 10 \\
& Ya & 33 & 79 \\
\hline \multirow{2}{*}{ Sumber Informasi } & Tidak & 9 & 21 \\
& Baik & 11 & 25 \\
& Cukup & 18 & 42 \\
\hline Mengetahui cara menggunakan first aid & Kurang & 13 & 33 \\
\hline kits & Ta & 19 & 45 \\
& Tidak & 23 & 55
\end{tabular}

Tabel 2 menunjukkan skor pretest pengetahuan menunjukkan rata-rata (mean) adalah 12,95 dengan standar deviasi adalah 1,912, skor minimal adalah 10 dan skor maksimal adalah 20. Sedangkan pada skor posttest pengetahuan menunjukkan rata-rata (mean) adalah 18,64 dengan standar deviasi adalah 2,058, skor minimal 15 dan skor maksimal adalah 23. Nilai $p$ value adalah 0,000 (ada perbedaan pengetahuan siswa sebelum dan sesudah diberikan demonstrasi first aid kits.

Tabel 2. Pengetahuan Sebelum dan Sesudah diberikan Demonstrasi Tentang Penggunaan First Aid Kits (n=42)

\begin{tabular}{lccccc}
\multicolumn{1}{c}{ Pengetahuan } & Mean & Median & Std. Deviasi & Min-Maks & p-value \\
\hline Pretest Pengetahuan & 12.95 & 12,82 & 1.912 & $10-20$ & \multirow{2}{*}{0,000} \\
Posttest Pengetahuan & 18.64 & 19,00 & 2.058 & $15-23$ & \\
\hline
\end{tabular}

Hasil table 3 menunjukkan skor pretest untuk keterampilan menunjukkan rata-rata (mean) adalah 53,14 dengan standar deviasi adalah 4,646, skor minimal 44 dan skor maksimal 66. Posttest keterampilan skor rata-rata (mean) adalah 68,12 dengan standar deviasi 3,749, skor minimal 59 dan skor maksimal 75 . Hasil uji $t$ berpasangan (Paired sample $t$ test) pada pengetahuan dan skills menunjukkan nilai signifikasi $0,000 \quad(p<0,05)$, yang berarti ada perbedaan signifikan keterampilan siswa SMK 3 Blitar antara yang diberi pendidikan kesehatan metode demosntrasi pada pretest dan posttest.

Tabel 3. Keterampilan Sebelum dan Sesudah diberikan Pendidikan Kesehatan dengan Metode Demonstrasi Tentang Penggunaan First Aid Kits ( $n=42)$

\begin{tabular}{lccccc}
\hline \multicolumn{1}{c}{ Keterampilan } & Mean & Median & Std. Deviasi & Min-Maks & p-value \\
\hline Pretest Keterampilan & 53.14 & 53,50 & 4.646 & $44-66$ & 0,000 \\
Posttest Keterampilan & 68.12 & 69,00 & 3.749 & $59-75$ & \\
\hline
\end{tabular}

PEMBAHASAN

Pengetahuan Siswa SMK yang diberi pendidikan metode Demonstrasi
Berdasarkan hasil penelitian ada perbedaan pengetahuan siswa SMK dalam penggunaan first aid kits sebelum dan sesudah 
dilakukan metode demonstrasi karena metode demonstrasi merupakan metode pengajaran yang perhatian terpusat pada guru (teacher centered) dengan komunikasi biasanya bersifat satu arah (one way communication). Metode ini adalah metode mengajar dengan cara memperagakan barang, kejadian, aturan, dan urutan melakukan suatu kegiatan, baik secara langsung maupun melalui media pengajaran yang relevan dengan pokok bahasan atau materi yang sedang disajikan. Tujuan pokok penggunaan metode ini dalam proses belajar mengajar adalah untuk memperjelas pengertian konsep dan memperlihatkan cara melakukan sesuatu atau proses terjadinya sesuatu (Syah, 2011). Dikatakan juga dengan metode demonstrasi pada hakikatnya adalah proses transfer informasi dari pengajar kepada sasaran didik (Djaramah \& Zain, 2012). Informasi yang diperoleh baik dari pendidikan formal maupun non formal dapat memberikan pengaruh pada ingatan jangka pendek (immediate impact) sehingga memberikan landasan kognitif baru bagi terbentuknya pengetahuan atau peningkatan pengetahuan (Notoatmodjo, 2012).

Sesuai dengan penelitian yang dilakukan oleh Yusniawati $d k k$ (2020) yang melakukan demonstrasi secara langsung terhadap siswa SMA dalam memberikan pertolongan pertama korban kecelakaan dapat meningkatkan pengetahuan siswa setelah diberikan metode demonstrasi langsung karena siswa ditunjukkan secara langsung langkah-langkah dalam melakukan pertolongan sehingga terjadi transfer informasi untuk meningkatkan pengetahuan. Demikian juga penelitian yang dilakukan oleh Prasetyawan dkk (2019) yang menyatakan ada peningkatan pengetahuan siswa setelah diberikan metode demonstrasi karena siswa ditunjukkan langkah-langkah atau proses dalam memberikan pertolongan pertama sehingga proses belajar menjadi lebih mudah, siswa ditunjukkan kondisi nyata dan diajak secara lebih aktif dalam belajar sehingga meningkatkan pengetahuan.
Pada metode demonstrasi alat bantu pembelajaran pada dasarnya dapat membantu sasaran didik untuk menerima pelajaran dengan menggunakan panca inderanya. Pada prinsipnya bahwa pengetahuan yang ada pada setiap manusia itu diterima atau ditangkap oleh panca indra, semakin banyak panca indra yang digunakan dalam menerima pelajaran yang disampaikan maka akan semakin jelas pengertian yang diperoleh yang akhirnya meningkatkan pengetahuan (Notoatmodjo, 2012). Menurut Lee, S.J \& Reeves, T.C (2018) sesuai dengan Edgar Dale's Cone of Experience metode demonstrasi yang termasuk dalam pembelajaran dengan observasi maka gambaran kemampuan partisipan dalam mengingat kembali pesan yang disampaikan dengan mendengar dan melihat adalah akan mengingat 50\% dari apa yang didengar dan dilihatnya. Sehingga pembelajaran ini memberikan pengalaman yang nyata dan konkret sehingga memudahkan peserta didik dalam belajar sehingga meningkatkan pengetahuan, Sehingga adanya peningkatan pengetahuan dengan metode demonstrasi karena peserta didik berfokus pada indera melihat dan mendengar apa yang didemonstrasikan yang merupakan informasi baru sebagai landasan kognitif terbentuknya pengetahuan.

\section{Keterampilan Siswa SMK yang diberi pendidikan kesehatan metode Demonstrasi}

Berdasarkan hasil penelitian ada perbedaan pengetahuan siswa SMK dalam penggunaan first aid kits sebelum dan sesudah dilakukan metode demonstrasi karena pemilihan yang tepat pada metode yang digunakan. Berdasarkan penelitian Munesswari (2014) menyatakan bahwa terdapat korelasi yang positif antara pengetahuan dan keterampilan yang dibuktikan dengan pengetahuan yang meningkat setelah posttest juga mempengaruhi kemampuan dalam melakukan keterampilan menjadi lebih baik, karena peningkatan pengetahuan merupakan langkah pertama untuk melakukan 
keterampilan secara benar. Diperkuat oleh Abd El-Hay, Ibrahim \& Hassan (2015) yang menyatakan bahwa dengan peningkatan pengetahuan maka akan meningkatkan pemahaman dan motivasi siswa dalam melakukan prosedur pertolongan pertama dengan benar.

Peningkatan keterampilan juga dipengaruhi oleh pemilihan metode yang benar. Metode pembelajaran adalah alat dan cara dalam pelaksanaan strategi belajar mengajar. Dasar pemilihan metode pembelajaran dalam pendidikan kesehatan bergantung pada beberapa faktor yaitu karakteristik sasaran/partisipan (jumlah, status sosial ekonomi, umur, jenis kelamin), waktu dan tempat yang tersedia, serta tujuan spesifik yang ingin dicapai dalam pendidikan kesehatan tersebut (perubahan pengetahuan, sikap atau praktik partisipan) misalnya teknik dan media (pengalaman langsung) yang digunakan dalam pendidikan kesehatan menstimulasi paling banyak indra partisipan, di sini keterampilan motorik dan sikap partisipan diasah sehingga metode ini sesuai untuk mengubah sikap dan keterampilan partisipan. Sehingga apabila tujuan spesifik pendidikan kesehatan untuk meningkatkan sikap, tindakan \& keterampilan maka metode pendidikan kesehatan yang tepat adalah diskusi kelompok, demonstrasi atau metode permainan (Nursalam \& Efendi, 2012). Pada dasarnya metode membantu sasaran didik untuk menerima pelajaran dengan menggunakan panca inderanya. Semakin banyak panca indera yang digunakan dalam menerima pelajaran semakin baik penerimaan pelajaran tersebut (Notoatmodjo, 2012). Dengan demonstrasi langsung maka semua indera digunakan oleh peserta dalam menerima pembelajaran menjadi bukti bahwa pengetahuan, keterampilan dan kemampuan yang diperoleh akan semakin meningkat.

\section{KESIMPULAN}

Ada perbedaan yang signifikan pada pengetahuan dan keterampilan siswa SMK 3 Blitar antara yang diberi pendidikan kesehatan metode demonstrasi karena demonstrasi langsung maka semua indera digunakan oleh peserta dalam menerima pembelajaran menjadi bukti bahwa pengetahuan, keterampilan dan kemampuan yang diperoleh akan semakin meningkat.

\section{REFERENSI}

Abd El-Hay, S., Ibrahim, N.A., Hassan, L.A. (2015). Effect of Training Program Regarding First Aid and Basic Life Support on the Management of Educational Risk injuries among Students in Industrial Secondary Schools. IQSR Journal of Nursing and Health Science, 4 (6): 32-43

Badan Penelitian dan Pengembangan Kesehatan Kementerian Kesehatan RI. (2018). Laporan Nasional Riset Kesehatan Dasar 2018. Jakarta: Kementerian Kesehatan Republik Indonesia

Badan Penelitian dan Pengembangan Kesehatan Kementerian Kesehatan RI. (2014). Laporan Nasional Riset Kesehatan Dasar 2018. Jakarta: Kementerian Kesehatan Republik Indonesia

Djamarah, S.B. \& Zain, A. (2012). Strategi Belajar Mengajar, Edisi revisi, Jakarta: Rineka Cipta

Lee, S.J \& Reeves, T.C. (2018). Edgar Dale and The Cone of Experience in Foundations of Learning and Instructional Design Technology. Available in https://lidtfoundations.pressbooks.com/chapter/edgar -dale-and-the-cone-of-experiencel

Maguluru, S., Simba, B.V., Chaitanya, C.V., Deep, D.R., Mounika, D., Abhilash, G. (2018). Effectiveness of First Aid Training Among High School Students in Rural Guntur: A Pre and Post Design. International Journal of Current Advanced Research, February, 7 (2): $9872-9877$

Muneeswari B. A study to Assess the Effectiveness of Planned Health Teaching Program Using Child to Child Approach on Knowledge of Selected First Aid Measures among School Children in Selected Schools at Dharapuram in Tamil Nadu, India. Global Journal of Medicine and Public Health, 3(1): 18-19.

Notoatmodjo, S. (2012). Promosi Kesehatan dan Perilaku Kesehatan Edisi Revisi 2012. Jakarta: Rineka Cipta

Nursalam \& Efendi, F. (2012). Pendidikan Dalam Keperawatan. Jakarta: Salemba Medika 
Jurnal SMART Keperawatan, 2021, 8 (2), 142-148

DOI: http://dx.doi.org/10.34310/jskp.v8i2.515

SJKP 2021

http://stikesyahoedsmg.ac.id/ojs/index.php/sjkp

Piazza, G.M. (2014). First Aid Manual $5^{\text {th }}$ Edition. New York: American College of Emergency Physicians

Prasetyawan, R.D., Fitri, L.E., Setyoadi. (2019). Both Peer Education and Demonstration Method Improve Student's Knowledge in First Aid of Traffic Accident. The Malaysian Journal of Nursing, 11 (1): 63-67

Russel, R., Halcomb, E., Caldwell, E., Sugrue, M. (2004). Differences in Mortality Predictions Between Injury Severity Score Triplets: a Significant Flaw. J Trauma, Jun, 56 (6): 1321-4
Syah, M. (2011). Psikologi Pendidikan dengan Pendekatan Baru. Bandung: PT Remaja Rosdakarya

Yusniawati, Y.N.P., Maharyawan, I.W., Robani, A. (2020). Differences in The Effectiveness of The Direct Demonstration Method and Video Screening of First Aid in Traffic Accidents on The Increase in Knowledge of Senior High School Students. Nurse and Health: Jurnal Keperawatan, 9 (2): 133-138 